\title{
Integrated Effect of Organic and Inorganic Sources of Nutrients on the Yield and Quality of Ginger (Zingiber officinale Rosc.)
}

\author{
A. Shadap ${ }^{1^{*}}$, A. Pariari ${ }^{2}$ and Y.A. Lyngdoh ${ }^{3}$ \\ ${ }^{1}$ Department of Horticulture, School of Agriculture, Lovely Professional University, \\ Phagwara, Punjab-144411, India \\ ${ }^{2}$ Department of Spices and Plantation Crops, Bidhan Chandra Krishi Viswavidyalaya, \\ Mohanpur-741 252, Nadia, West Bengal, India \\ ${ }^{3}$ Division of Vegetable Science, ICAR-IARI, New Delhi, India \\ *Corresponding author
}

\section{A B S T R A C T}

\begin{tabular}{|c|}
\hline Keywords \\
\hline $\begin{array}{l}\text { Ginger, Organic, } \\
\text { Bio-fertilizer, Yield, } \\
\text { Quality }\end{array}$ \\
\hline Article Info \\
\hline $\begin{array}{l}\text { Accepted: } \\
07 \text { March } 2018 \\
\text { Available Online: } \\
10 \text { April } 2018\end{array}$ \\
\hline
\end{tabular}

A field experiment was conducted to assess the yield and quality of ginger treated with different combinations of organic and inorganic nutrition. Among the different treatments, maximum number of rhizome per clump (16.64), girth of fingers $(2.34 \mathrm{~cm})$, length of fingers $(10.20 \mathrm{~cm})$ and clump length $(21.25 \mathrm{~cm})$ were observed in plants raised with Vermicompost + NPK 75\% + Azospirillum + VAM + PSB $\left(\mathrm{T}_{5}\right)$. This combination also produced the highest essential oil $(1.57 \%)$ and oleoresin content $(5.34 \%)$. However, the recovery of dry ginger was maximum $(21.96 \%)$ in $\mathrm{T}_{1}$ (Compost + NPK $100 \%+$ Azospirillum + VAM + PSB) which was at par with $\mathrm{T}_{7}$ (Neemcake + NPK $100 \%+$ Azospirillum + VAM + PSB) and $\mathrm{T}_{4}$ (Vermicompost + NPK 100\% + Azospirillum + $\mathrm{VAM}+\mathrm{PSB}$ ) with a recovery percentage of 21.95 and 21.94 per cent respectively. The highest yield/clump (162.23 g) was from the plants raised with Vermicompost + NPK 75\% + Azospirillum + VAM + PSB $\left(\mathrm{T}_{5}\right)$ followed by $\mathrm{T}_{8}-$ Neemcake + NPK $75 \%+$ Azospirillum + VAM + PSB (159.95 g). From Benefit : cost ratio point of view, the best treatment was observed in $\mathrm{T}_{5}$ - Vermicompost + NPK $75 \%+$ Azospirillum + VAM + PSB (4.09) followed by $\mathrm{T}_{4}$ - Vermicompost $+\mathrm{NPK} 100 \%+$ Azospirillum + VAM + PSB (3.83), clearly indicating the chance of saving 25 per cent inorganic fertilizers.

\section{Introduction}

Ginger (Zingiber officinale Rosc.) is one of the major spices produced and exported from India. The rhizome of ginger is used as a spice throughout the world besides its use in the alternative system of medicine and plays an important role in primary health care. Ginger is an herbaceous perennial, rhizomatous spice crop containing volatile and non-volatile compounds responsible for the characteristic pungency of the ginger rhizome.

Ginger is a long duration and heavy feeder crop and responds well to manuring and gives high return per unit area; but removes large quantity of nutrients from the soil which require heavy input of fertilizers. 
Continuous and indiscriminate use of chemical fertilizers pollutes the environment, soil and water besides increasing the cost of production. Organic manures and bio-fertilizer improves growth and yield of ginger by increasing availability and uptake of nutrients, other micronutrients and production of growth promoting substance. Organic manures and biofertilizers offer as an alternative to chemical inputs and are being increasingly used in spice production today. On the other hand, biofertilizers are cost effective and renewable source of plant nutrients to supplement the part of chemical fertilizers. Biofertilizers are beneficial microorganisms which are one of the low cost inputs and have the ability to mobilize the nutrients from nonavailable to available form besides producing growth promoting and antifungal substances (Tien et al., 1979; Sadanandan and Hamza, 1998; Jena and Das, 1997). Thus, they ensures saving a substantial amount of chemical fertilizers which eventually reduce the cost of production. In ginger, Azospirillum can reduce $50 \%$ of the recommended nitrogenous chemical fertilizers besides increasing fresh rhizome yield over recommended dose of chemical fertilizers. Therefore, keeping in view of the above facts, an experiment was conducted using nutrients from different organic and inorganic sources to work out their suitable integration for better yield and quality of ginger.

\section{Materials and Methods}

The experiment was conducted at Horticultural Research Station, Mondouri, B.C.K.V. for two consecutive years (2012-13). Topographical situation of the experimental site belongs to the Gangetic New Alluvial plains of West Bengal. The soil was sandy loam and slightly acidic in nature. In general the experimental site was having uniform fertility and good drainage facility and comes under sub-tropical humid climate as it is situated just south of tropic of cancer. The experiment was laid out in Randomized Block Design with three replications. Three biofertilizers namely Azospirillum, VAM and PSB and three organic manures (compost, vermicompost and neemcake) were included as bio-organic inputs. The bio-fertilizers were applied in combination with organic manures and inorganic fertilizers. All together there are 19 treatments including one control without any treatments. After the final land preparation, compost @ 25 tonnes/ha, Vermicompost @ 2 tonnes/ha and Neemcake @ 3 tonnes/ha were applied along with recommended dose of fertilizers (NPK: 80: 50: $60 \mathrm{~kg}$ per ha) in the form of Urea, Single Super Phosphate and Muriate of Potash, respectively, either as full dose $(100 \%)$ or at reduced rate $(75 \%$ or $50 \%$ of $\mathrm{RDF}$ ) according to treatment details. Nitrogen was applied in two split doses, the first dose as basal application and the other dose at 30 days after planting as top dressing. The entire dose of Phosphorus and Potash were applied at the time of sowing as basal dose. The Biofertilizers viz., Azospirillum @ $10 \mathrm{~kg} / \mathrm{ha}, \mathrm{VAM}$ @ $40 \mathrm{~kg} / \mathrm{ha}$ and PSB @ $10 \mathrm{~kg} / \mathrm{ha}$ )were mixed with organic manures and soil thoroughly and applied to the beds just before planting. The ginger variety 'Nadia' was used in the experiment. Ginger seed rhizomes of size $25 \mathrm{~g}$ each treated with Trichoderma viride (@5 $\mathrm{g} / \mathrm{kg}$ seed rhizome) were planted on raised bed of size $3 \times 1 \mathrm{~m}$ at a spacing of $30 \mathrm{~cm} \times 25 \mathrm{~cm}$. Mulching was done on the beds immediately after planting by using dried paddy straw as mulching materials. It is repeated 60 days later after weeding and top dressings as per treatment requirements. Earthing up was carried out to cover the exposed rhizome as and when necessary. Irrigation was provided immediately after planting and fertilizer application. Depending on the rainfall and soil moisture conditions, further irrigations were given as required. Hand weeding was done at an interval of 30 days from planting until the 
complete coverage of canopy. The crop was harvested after complete maturity as indicated by withering and drying up of leaves and tillers nine months after planting. Observations on yield parameters were recorded on five randomly selected clumps in each treatment after harvest. Essential oil and oleoresin content were analysed after harvest adopting standard procedure (AOAC, 1975). Statistical analysis and interpretation of data was done as given by Panse and Sukhatme (1985). The level of significance used in ' $F$ ' and ' $t$ ' test was at $\mathrm{P}=0.05$. The economic analysis of different treatments was worked out based on corresponding cost of inputs and market prices.

\section{Results and Discussion}

The effect of different treatments on the yield and quality of ginger are presented in Table 1 and Figure 1 and 2. Significant results were obtained on yield parameters such as number of rhizome per clump (16.64), girth of fingers $(2.34 \mathrm{~cm})$, length of fingers $(10.20 \mathrm{~cm})$, clump length $(21.25 \mathrm{~cm})$ and yield per clump (162.23 g) which were found to be higher in the plants raised with Vermicompost + NPK $75 \%+$ Azospirillum + VAM + PSB $\left(\mathrm{T}_{5}\right)$. Whereas, maximum clump breadth $(11.35 \mathrm{~cm})$ was recorded in the plants raised with Vermicompost + NPK 100\% + Azospirillum + $\mathrm{VAM}+\mathrm{PSB}\left(\mathrm{T}_{4}\right)$.

Combined application of organic manures, biofertilizers and inorganic fertilizers had beneficial effect on yield and yield attributing characters. The increase in yield was largely as a consequence of cumulative effect of the plant growth characters (Singh and Singh, 2007). Among the organic manures, the combinations where vermicompost was applied produced better performance and higher yield than Neemcake and Compost. The findings are in good agreement with the observations of earlier workers in ginger
(Jana, 2006; Sanwal et al., 2007; Dash et al., 2008 and Rana and Korla, 2010). The data analysis on quality parameters such as essential oil, oleoresin and dry recovery percentage were significant. Maximum essential oil $(1.57 \%)$ and oleoresin content $(5.34 \%)$ was obtained in the treatment $\mathrm{T}_{5}$ (Vermicompost + NPK 75\% + Azospirillum + $\mathrm{VAM}+\mathrm{PSB}$ ), however, the recovery of dry ginger was maximum $(21.96 \%)$ in $\mathrm{T}_{1}$ (Compost + NPK 100\% + Azospirillum + $\mathrm{VAM}+\mathrm{PSB})$ which was at par with $\mathrm{T}_{7}$ (Neemcake + NPK 100\% + Azospirillum + $\mathrm{VAM}+\mathrm{PSB}$ ) and $\mathrm{T}_{4}$ (Vermicompost $+\mathrm{NPK}$ $100 \%+$ Azospirillum + VAM + PSB) with a recovery percentage of 21.95 and 21.94 per cent. The data in the table clearly shows that application of biofertilizers certainly increases the performance of ginger in terms of yield and quality compared to other treatments with similar organic manures and inorganic nutrition combination.

The improvement in quality in these treatments may be attributed to the organic inputs (organic manures and biofertilizers) along with inorganic fertilizers which improved the physico-chemical and biological properties of the soil which enable roots to proliferate resulting in better utilization and absorption of NPK and micronutrients required for enhancing the quality of the rhizome. The results in this study are in accordance with the observation of earlier workers who reported similar findings in ginger (Rana and Korla, 2010; and Jana, 2006). Dash et al., (2008) reported that biofertilizers have a positive bearing in enhancing the quality of ginger. Sanwal et al., (2007) reported that the oleoresin content of ginger treated with different organic manures were higher compared to sole inorganic application. Sadanandan et al., (2002) also reported that application of organic manure and biofertilizers increased the oleoresin content in ginger. 
Table.1 Effect of organic manures, biofertilizers and graded dose of fertilizers on yield and quality of ginger cv. Nadia (mean of 2 years)

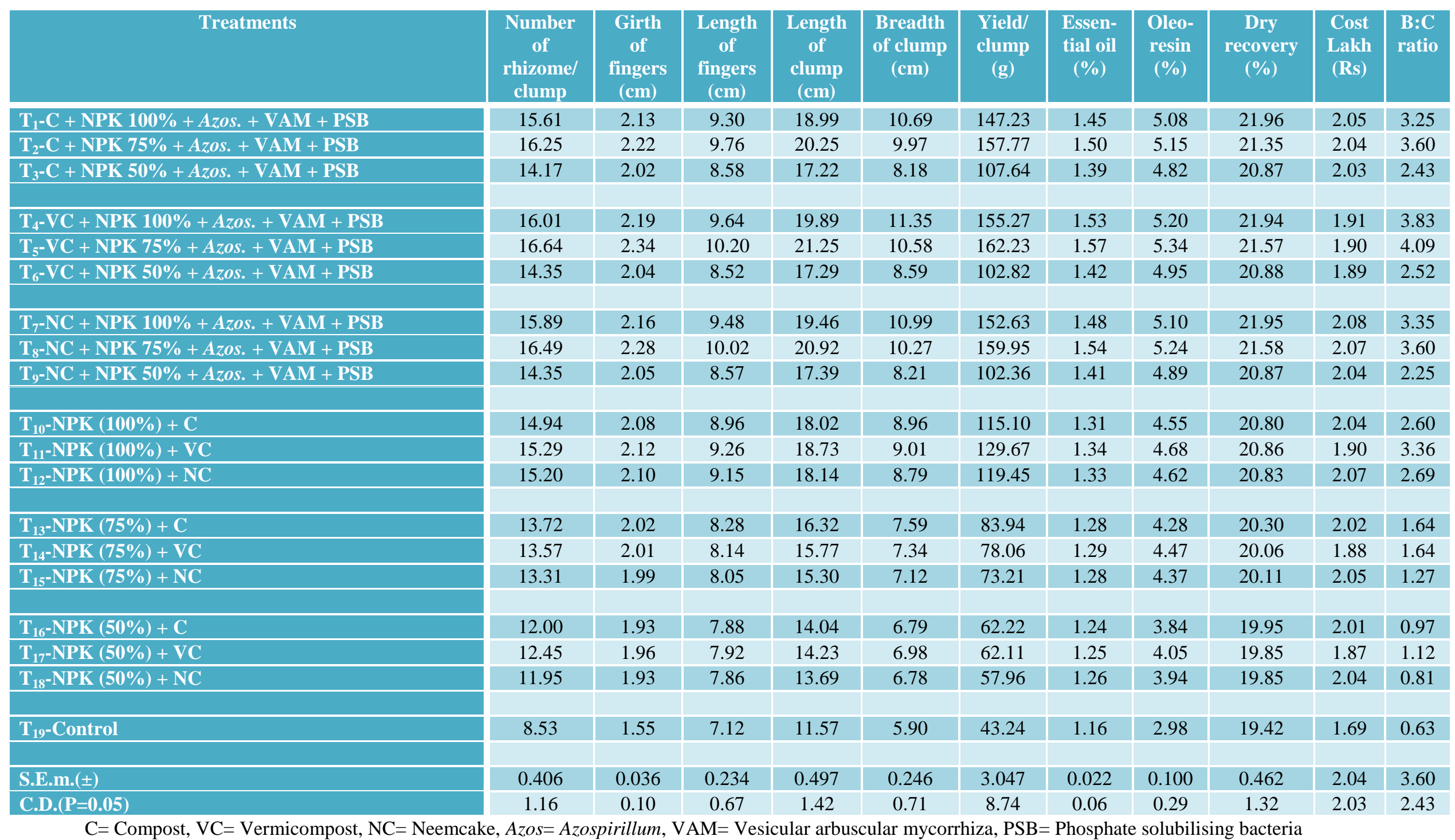




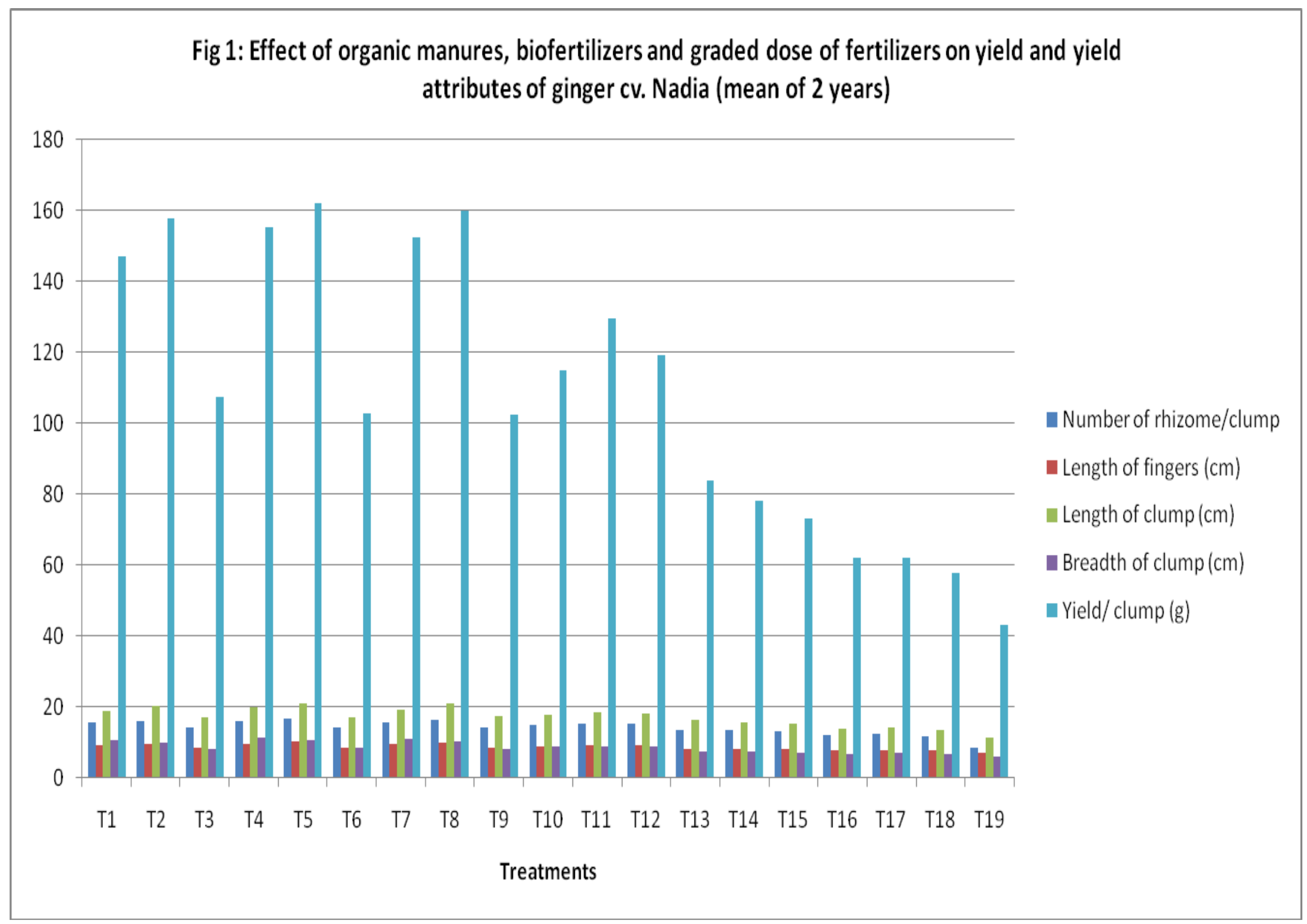




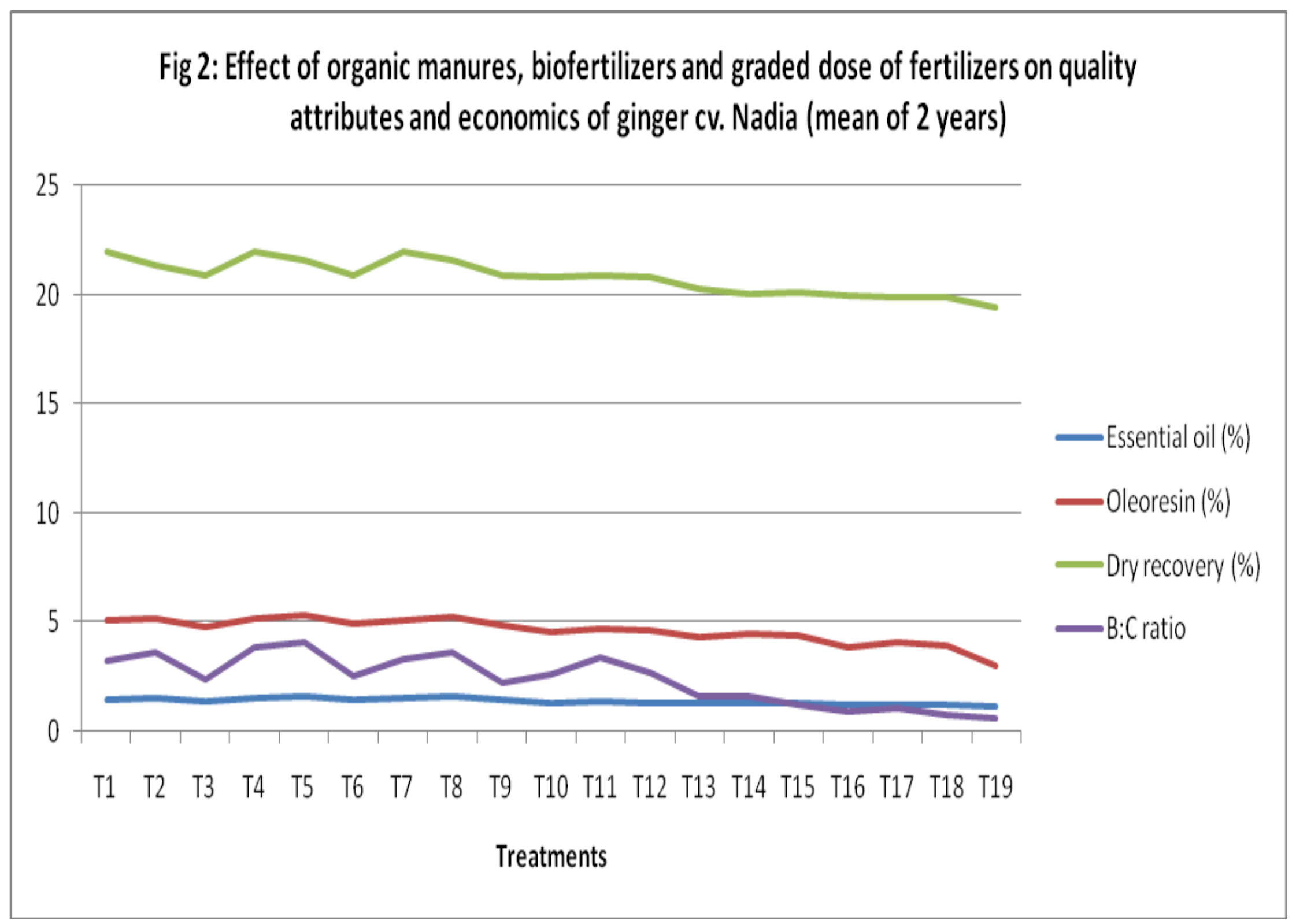


In the present study also the plants raised with the integration of organic manures (Vermicompost, neemcake and compost), biofertilizers (Azospirillum, VAM and PSB) and higher doses of inorganic NPK resulted in higher content of quality parameters such as essential oil and oleoresin as well as recovery percentage.

Economic analysis indicated that the best treatment in terms of Benefit : cost ratio was observed in $\mathrm{T}_{5}-$ Vermicompost $+\mathrm{NPK} 75 \%+$ Azospirillum + VAM + PSB (4.09) followed by $\mathrm{T}_{4}$ - Vermicompost + NPK $100 \%+$ Azospirillum + VAM + PSB (3.83) and thus, clearly indicating the chance of saving 25 per cent inorganic fertilizers.

Thus, an integrated approach of organic and inorganic nutrition can increase the yield and quality of ginger.

\section{References}

AOAC. (1975). Association of official analytical chemists, Washington, USA.

Dash, D. K., Mishra, N. C. and Sahoo, B. K. 2008. Influence of nitrogen, Azospirillum sp. and farm yard manure on the yield, rhizome rot and quality of ginger (Zingiber officinale Rosc.). J. Spices and Aromatic Crops. 17(2): 177-179.

Jana, J. C. 2006. Effect of Azospirillum and graded levels of nitrogenous fertilizer on growth, yield and quality of ginger (Zingiber officinale Rosc.). Environment and Ecology. 24S (Special 3): 551-553.

Jena, M. K. and Das, P. K. 1997. Influence of microbial inoculants on quality of turmeric. Indian Cocoa, Arecanut and Spices J., 21(2): 31-33.
Panse, V. G. and Sukhatme, P. V. 1985. Statistical Methods for Agricultural Workers. Indian Council of Agricultural Research, New Delhi.

Rana, N. and Korla, B. N. 2010. Integrated farming with organic and inorganic fertilizers on yield and quality of ginger (Zingiber officinale Rosc.). Agric. Sci. Digest., 30(4): 250-253.

Sadanandan, A. K. and Hamza, S. 1998. Effect of organic farming on nutrient uptake, yield and quality of ginger (Zingiber officinale). In: Water-and-nutrientmanagement for sustainable production and quality of spices: Proceedings of the national seminar, Madikeri, Karnataka, India, 5-6 October, 1998. pp. 89-94.

Sadanandan, A. K., Srinivassan, V. and Hamza, S. 2002. Effect of integrated plant nutrient management on yield and quality of Indian spices. (In) Proceedings of National seminar on water and nutrient management for sustainable production and quality of spices, held during 5-6 October 1997 at IISR, Calicut, pp. 12-20.

Sanwal, S. K., Yadav, R. K. and Singh, P. K. 2007. Effect of types of organic manure on growth, yield and quality parameters of ginger (Zingiber officinale). Indian J. Agric. Sci., 77(2): 67-72.

Singh, V. B. and Singh, A. K. 2007. Effect of types of organic manure and methods of nitrogen application on growth, yield and quality of ginger. Environment and Ecology. 25(1): 103-105.

Tien, T. N., Gaskins, M. H. and Hubbell, D. H. 1979. Plant growth substances produced by Azospirillum brasilense and their effect on growth of pearl millet. Applied and Environment Microbiology. 30: 1016-1024.

\section{How to cite this article:}

Shadap, A., A. Pariari and Lyngdoh, Y.A. 2018. Integrated Effect of Organic and Inorganic Sources of Nutrients on the Yield and Quality of Ginger (Zingiber officinale Rosc.). Int.J.Curr.Microbiol.App.Sci. 7(04): 754-760. doi: https://doi.org/10.20546/ijcmas.2018.704.084 